\title{
New Findings on Rock Engravings in the Oukaïmeden Valley (High Atlas, Morocco) and Their Implications to the Local Transhumance
}

\author{
Barbora Půtová \\ Ústav etnologie Filozofické fakulty Univerzity Karlovy, nám. Jana Palacha 2, 11638 Praha 1
}

Received $13^{\text {th }}$ September 2016; accepted $10^{\text {th }}$ October 2016

\section{NOVÉ POZNATKY O SKALNÍCH RYTINÁCH V ÚDOLÍ OUKAÏMEDEN (VYSOKÝ ATLAS, MAROKO) A JEJICH VÝZNAM PRO LOKÁLNÍ TRANSHUMANCI}

\begin{abstract}
ABSTRAKT Předmětem studie je skalní umění v údolí Oukaïmeden, které se nachází v centrální části Vysokého Atlasu na území Maroka. Studie se zaměřje na konkrétní archeologické lokality, užité výtvarné techniky, stylové charakteristiky a další specifika místního skalního umění. Zvláštní pozornost je věnována motivům, vývojovým proměnám a datování skalního umění v údolí Oukaïmeden. Skalní umění se zde poprvé objevuje v pozdním neolitu, poté je rozvíjeno v pozdní době bronzové a přetrvává až do libyjsko-berberského období. V další části studie je představena interpretace motivů skalního umění včetně analýzy funkce a smyslu jejich umístění v krajině. V této souvislosti je popsán blízký vztah skalního umění $\mathrm{k}$ transhumanci, která přetrvává v oblasti Vysokého Atlasu až do současnosti. Cílem studie je popis a interpretace skalního umění v údolí Oukaïmeden s důrazem na sezónní užití vysokohorských pastvin berberskými pastevci.
\end{abstract}

KLÍČOVÁ SLOVA údolí Oukaïmeden; Vysoký Atlas; skalní umění; krajina, transhumance

ABSTRACT This paper deals with rock art in the Oukaïmeden Valley situated in the central part of the High Atlas in Morocco. The paper focuses on specific archaeological sites, the art techniques used, distinguishing features of the style and other specific features of the local rock art. Special attention is paid to the motifs, development changes and dating of rock art in the Oukaïmeden Valley. Rock art first appeared in the Oukaïmeden Valley in the Late Neolithic, It developed during the Late Bronze Age and continued until the Libyan-Berber period. The second part of the paper presents an interpretation of rock art motifs including the analysis of their function and meaning in the landscape. The paper describes the close relation between rock art and transhumance, in the High Atlas until these days. The paper describes and interprets rock art in the Oukaïmeden Valley emphasizing the seasonal use of mountain pastures by Berber shepherds.

\section{KEY WORDS Oukaïmeden Valley; High Atlas; rock art; landscape; transhumance}

\section{BASIC DESCRIPTION OF ROCK ART IN THE OUKAÏMEDEN VALLEY AND ITS RELATION TO OTHER ROCK ART SITES IN MOROCCO}

Rock Art in Morocco can be found in the southern foothills of the Anti-Atlas (especially in the Draa Valley) and penetrates the slopes of the High Atlas, but it cannot be found in the Middle Atlas and the Rif Mountains (Searight 2004). ${ }^{1}$

1 This output was created within the project Language, Identity,
The main centres of rock art in the High Atlas are: the Oukaïmeden Valley, Yagour Plateau and Jebel Rat, with some secondary sites such as Taïnant and Telouèt. The altitude of these localities exceeds 2000 metres and are endowed with pastures and natural resources (Simoneau 1977; Otto 1994; Alaoui

History in Contemporary Cultural Transformation, subproject Rock Art in the Oukaïmeden Valley, Morocco: Case Study solved at the Faculty of Arts, Charles University from the funding of the Specific university research in 2016 . 


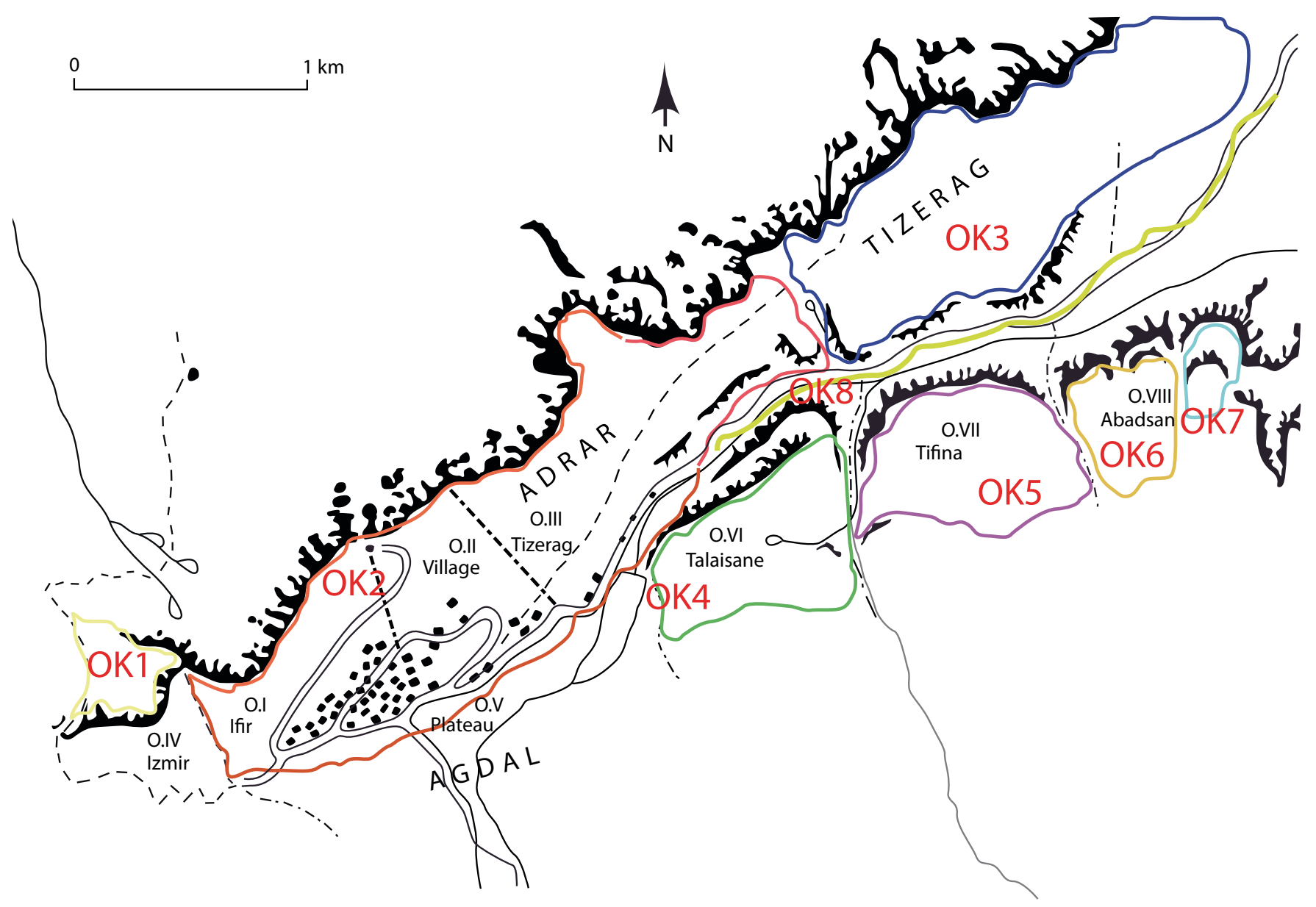

Map of the Oukaïmeden Valley rock art distribution. @ Kateřina Šišperová.

Haroni - Alifriqui - Simonneaux 2009; Rodrigue 2009). Engravings are found on sloping sandstone slabs, in rock shelters or small caves (Searight 2013). In comparison with caves in France and Spain, Moroccan localities are in the open air and rock art engravings are visible (Bravin 2014). The Oukaïmeden Valley is the core of the group of rock art in North Africa (Ruiz-Galvéz - Torres - Señorán et al. 2015). The Oukaïmeden Valley (W 752', N 31 ${ }^{\circ} 12^{\prime}$ ) is situated $2650 \mathrm{~m}$ asl in the centre of the High Atlas, some 75 kilometres from Marrakesh. ${ }^{2}$ The concentration of engravings in the Oukaïmeden Valley is unevenly balanced, covering an area of five square kilometres $^{3}$ (Rodrigue 2009).

2 At present, engravings in the valley are exposed to pollution and burden caused by cultural tourism. Tourists go on biking and trekking trips to the valley, or go on one-day trips returning to Marrakech usually after having lunch or dinner in one of the local restaurants (Ruiz-Galvéz - Presa 2014).

3 Just for comparison: engravings in Yagour are distributed in the distance of 13 kilometres, in Jebel Rat they are concentrated at the Tizi n'Tighist site (Glory 1953; Malhomme 1959, 1961).
Rock art in the Oukaïmeden Valley is distributed in eight different areas from OK1 to OK8. Rock art sites are spread mainly on S/SE slopes facing the sun, in that part of the valley best protected and warmest. OK1 includes the Izmir area, OK2 corresponds to areas previously named Ifir, Village, Tizerag and Plateau. OK3 area covers Tizerag, OK4 corresponds to Talaisane, OK 5 to Tifina and OK6 and OK7 cover the area previously known as Abadsan. OK8 is a new area including the Irini River and its banks. The areas are divided with natural borders formed by mountain passes and streams. Each area includes a different number of stations. OK5 stands out with 65 rock art stations, which is more than a quarter $(26.63 \%)$ of their total number in the Oukaïmeden Valley, although its surface is two times smaller than that of OK2 or OK3. One of the largest areas is OK6 with $15.16 \%$ of the rock art sites. OK2 is the second main entrance to the valley from the west that has been damaged first by stone-built summer settlements (azibs) built by the Berbers and later by huts, hotels and shops and even a garrison, dam and a resort (Rodrigue 1999, 2009; Collado Giraldo 2014; Ruiz-Galvéz - Bokbot - Collado Giraldo et al. 2013; Ruiz-Galvéz - Torres - Señorán et al. 2015). 


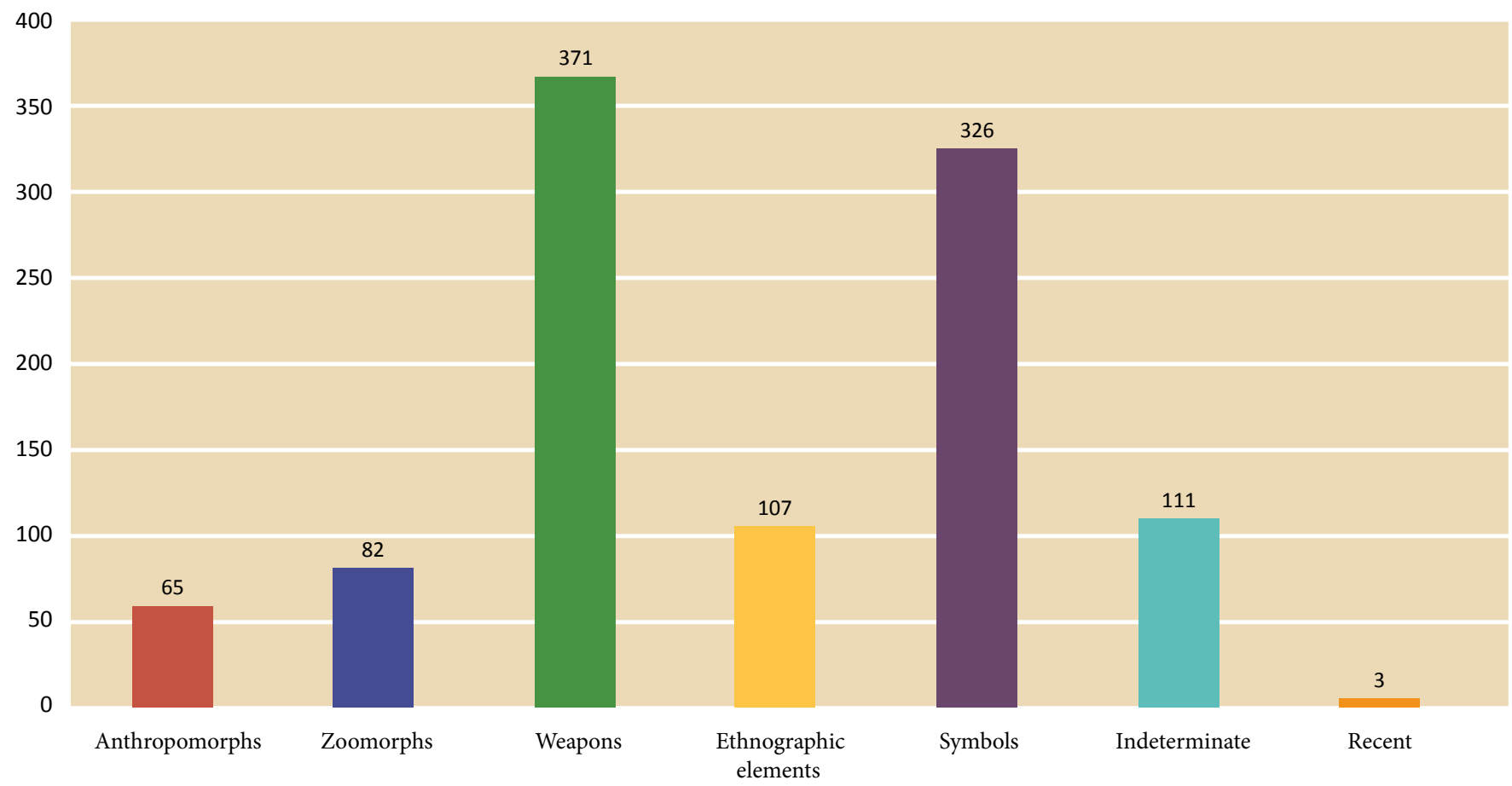

Distribution of rock art engravings in the Oukaïmeden Valley. ๑ Kateřina Šišperová.

\section{TECHNIQUES, CHARACTERISTICS AND DISTINGUI- SHING FEATURES OF ROCK ART IN THE OUKAÏMEDEN VALLEY}

The 1068 documented figures in the Oukaïmeden Valley were made by a variety of techniques such as pecking, abrading and thin incised trace. Most motifs were made by pecking, which is the case of more than 1000 images. It is a simple technique based on repeated and continuous pounding with a striking tool to make grooves. The depth of grooves depends on rock hardness, resistance of the striking tool and the strength of the impact. The width of grooves ranges between 0.7 and $3 \mathrm{~cm}$, usually it is around $1.2 \mathrm{~cm}$. The stability and depth of images is surprising. We may presume that motifs were first outlined on rock surface and then filled by pecking. "In some cases a pecked figure was later abraded, while in others figures were made in part by pecking and in part by abrading." (RuizGalvéz - Torres - Señorán et al. 2015: 1445) This technique is distributed across the valley: used particularly to make outlines, and only seldom to make fillings of images. Sometimes we can see partial fillings, especially in animals, for instance the neck and chest area. As for pecking used in the creation of images in the valley, it cannot be determined that the impacts on the rock surface were direct or indirect. No tools have been documented. The same technique was applied in the Côa Valley, where two quartzite stones used for direct pecking were found at the site of Olga Grande 4 . The preferential use of direct pecking in is apparent in open air rock art localities (Jodin 1966; Salih - Oujaa - Heckendorf et al. 1998; Collado Giraldo 2014; Půtová 2015).
The second most often represented technique in the Oukaïmeden Valley is abrading with 49 engraved figures in OK2 and OK5. Abrading is characterized by thickness between 0.8 and $1 \mathrm{~cm}$. While pecking is used in all types of figures in the valley, abrading prevails in weapons. Combination of pecking and abrading has been documented in 18 motifs. In many cases, outlines of motifs were first pecked and rubbing or abrading followed. Thin incised traces are exceptional, documented only once at OK2 area rock art station (Jodin 1966; Collado Giraldo 2014; Ruiz-Galvéz - Torres - Señorán et al. 2015).

There is only minimal relationship or interaction between the rock surface and the motifs depicted on the surface can be seen in the valley. At some places, rock surface irregularities (hollows or exfoliations) are used as a part of a motif or as an entire motif, for instance in OK3 area. At some places, the curve of an animal body corresponds with a protrusion, curvature or irregular frame surface. Rock art in the open air is engraved on a simple detached and isolated sandstone slab and on flat or slightly sloped sandstone outcrop. The colour of motifs is monotonous, ranging from reddish to greyish including variations of their shades. Reddish colour (60\%) prevails over greyish (40\%). However, colour was not the basic criterion for selecting the surface for carving (Searight 2013; Collado Giraldo 2014).

\section{ROCK ART MOTIFS REPRESENTED IN THE OUKAÏMEDEN VALLEY}

The Oukaïmeden Valley is characterized by motifs that differ in technique, typology and style. Motifs in the Oukaïmeden 


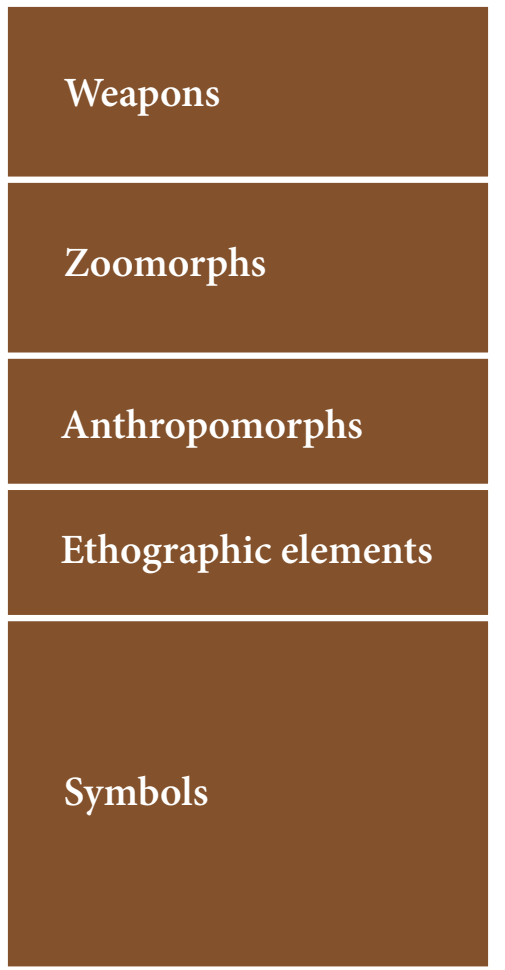

daggers, maces, hammers, halberds, swords, axes,

spears, arrows, slings

bovine, horses, deers, goats, canidae, felines, elephants, rhinoceros, buffalos, snakes

naturalistic subtype, violin subtype, schematic subtype, idols

shields, necklaces, topographic maps (or games), epigraphy

linear open structures (straight, simple, double, curved or undulated lines and spirals)

linear closed structures (oval forms, squares, rectangles, triangles, tectiform, foots)

Typological classification of rock art engravings in the Oukaïmeden Valley. (C) Kateřina Šišperová.

Valley can be divided in seven groups: 1) Weapons (371 motifs), 2) Zoomorphs (82 motifs), 3) Anthropomorphs (65 motifs), 4) Ethnographic elements (107 motifs), 5) Symbols (326 motifs), 6) Indeterminate (111 motifs) and 7) Recent depictions (3 motifs). In many cases, as in anthropomorphic and zoomorphic motifs, the development from naturalism to schematism and reduction in iconography is quite apparent. Detailed figures with weapons and other symbols gradually change in schematic depictions. Motifs are only rarely larger than $50 \mathrm{~cm}$, but some of them, including anthropomorphs, may be life-sized (Souville 1991; Bravin 2014; Collado Giraldo 2014).

The High Atlas contains mostly motifs of weapons, including daggers, maces, hammers, halberds, swords, axes, spears, arrows or slings. The most numerous depictions of weapons are daggers consisting of a handle and a blade. The motif of daggers varies in pommels, guards and presence or absence of a midrib and rivets. The handle is usually made up of two concave lines that are joined with a triangular blade with or without midrib. Later the size of the handle grows, in several cases the handle is even larger than the blade. Daggers always overlap zoomorphic motifs. The oldest type of daggers is linked to anthropomorphs of the naturalistic subtype. Just as various features of anthropomorphs develop, the same applies to daggers, as their handles become bigger and more and more complex. Other weapons represented are maces, hammers and halberds. Halberds are often superimposed or underlie daggers and maces that are typically oval, square or circular. Their handle is either short and slightly curved or straight and elongated. By contrast, halberds are characterized with elongated triangular blades embedded in shafts ending with a small rounded bulk. Types of metal weapons documented in the Oukaïmeden Valley are morphologically similar to motifs on the Iberian Peninsula (Rodrigue 2009; Collado Giraldo 2014).

In addition to weapons, other frequently depicted motifs are zoomorphs - wild or domestic animals made with various techniques or degrees of schematization. The animals depicted correspond with the species living in the High Atlas. Zoomorphic motifs are characterized, in addition to certain identification of the taxonomical affiliation and naturalism, by repeating the forms of depicting anatomic parts and details such as horns, tusks or tails. Most animals are engraved in a lateral perspective or in a profile view. Their bodies can be engraved in outlines, filled or internally divided with a single vertical line around the neck and back area. All animals in the Oukaïmeden valley are hieratical with no relation to the surrounding landscape or rock surface. Engravings are static and don't form complex compositions or scenes showing more than one depiction. Only seldom can we see engravings of a group of animals on a panel. Zoomorphic motifs in the Oukaïmeden Valley include bovine, horses, deer, goats, canidae, felines, elephants, rhinoceros, buffalos and snakes. Most frequently represented animals are bovines. "Nevertheless, as still today in many Mediterranean countries, the social, symbolic and economic value of bovines was paramount." (Torres Ruiz-Galvéz 2014: 186) Bovines are distinguished with a rectangular body in profile and a vaulted ventral curve. A head 


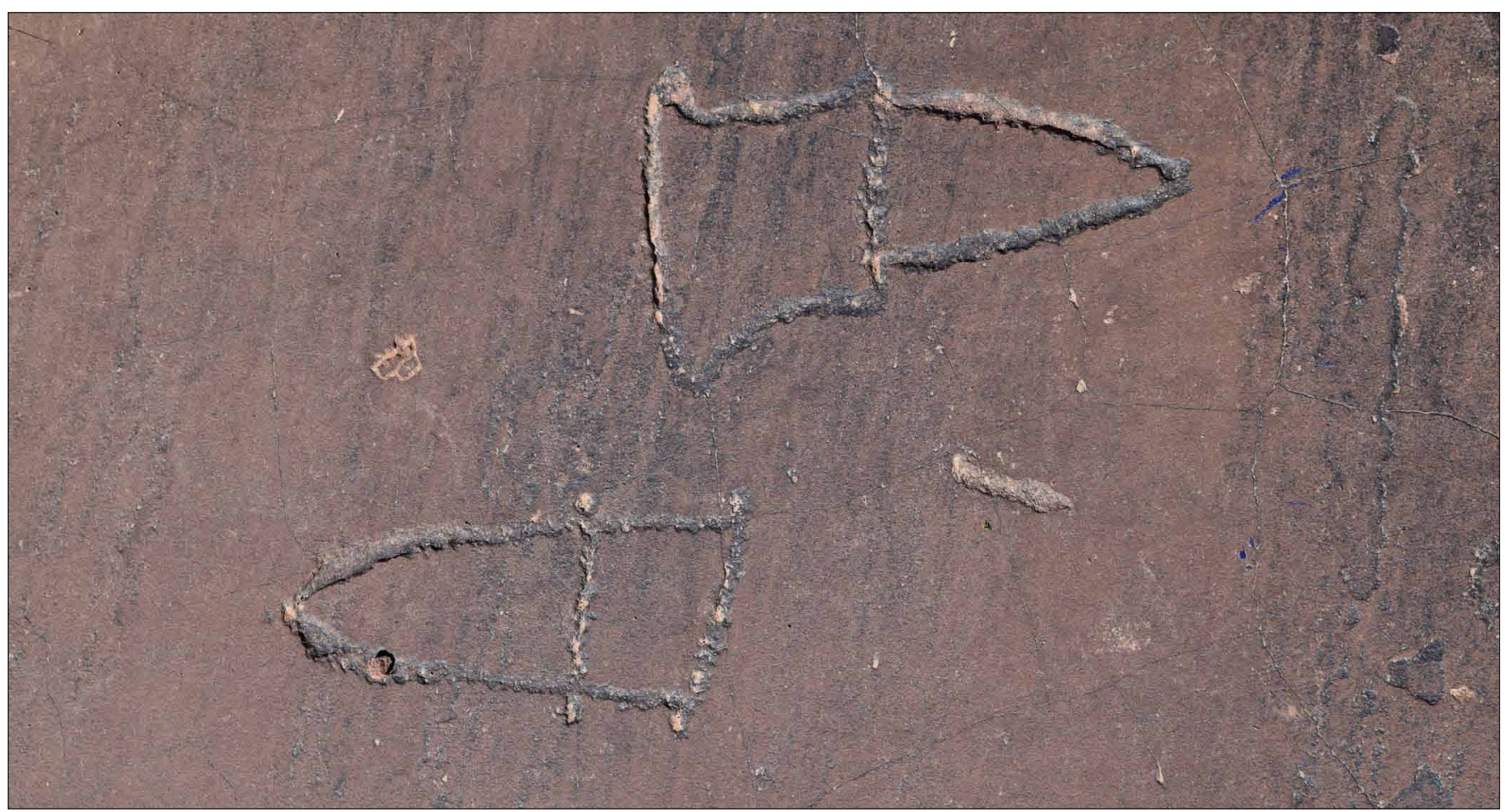

Typology of weapons in the Oukaïmeden Valley - daggers. (c) Barbora Půtová.

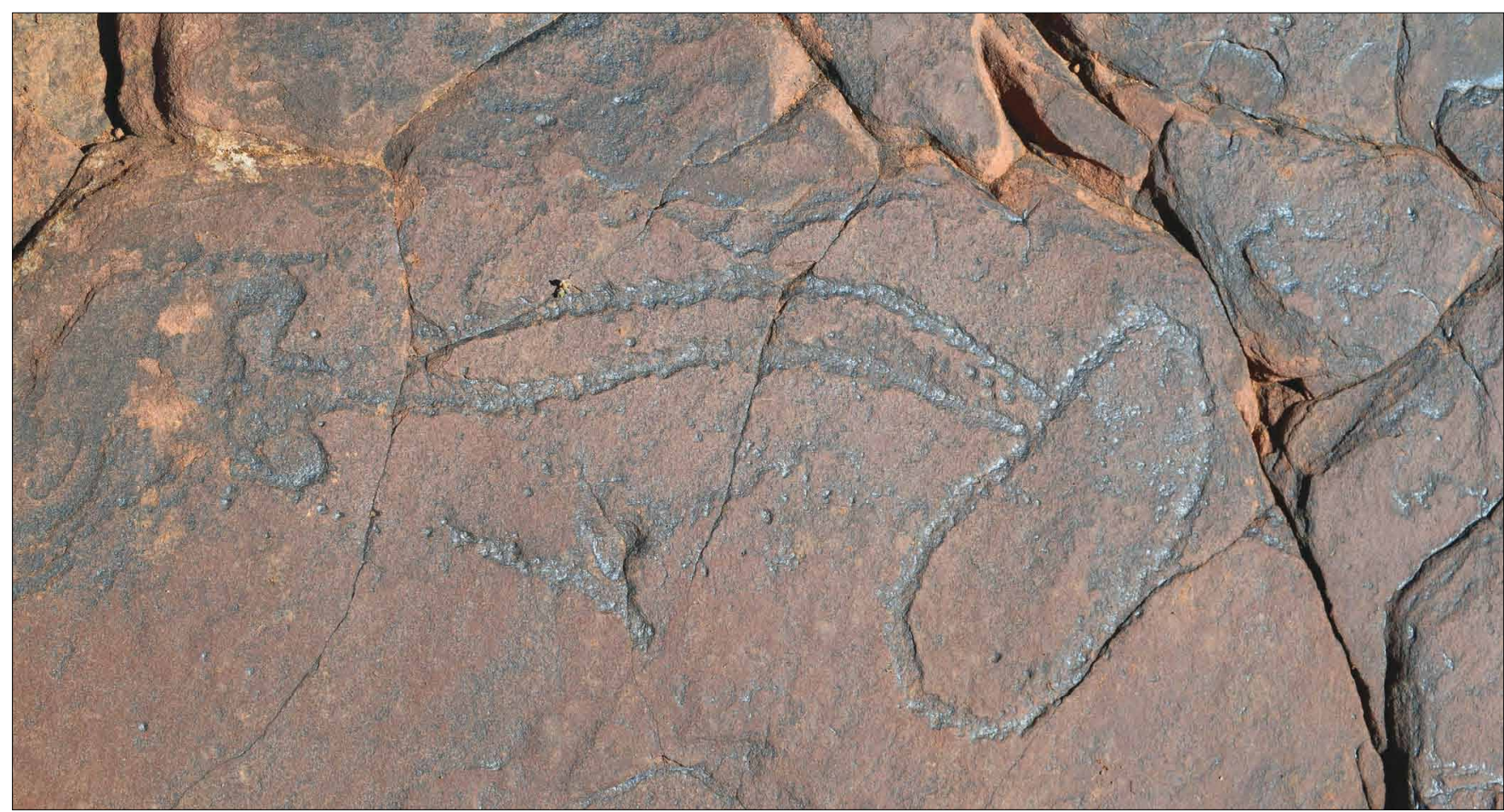

Typology of weapons in the Oukaïmeden Valley - mace. (c) Barbora Půtová.

with lyre-shaped horns is usually disproportionately small when compared with the body. Bovines are also characterized with sexual organs and the characteristic tail (Kaache 2001; Searight 2004; Le Quellec 2008; Bravin 2009, 2014; Rodrigue 2009; Collado Giraldo 2014).
Anthropomorphic motifs executed with an incision or pecking technique consist of the trunk, upper and lower limbs. Sometimes the head is schematized. Figures are often accompanied by weapons. Anthropomorphic motifs are divided in three main subtypes of human figures: naturalistic, violin and sche- 


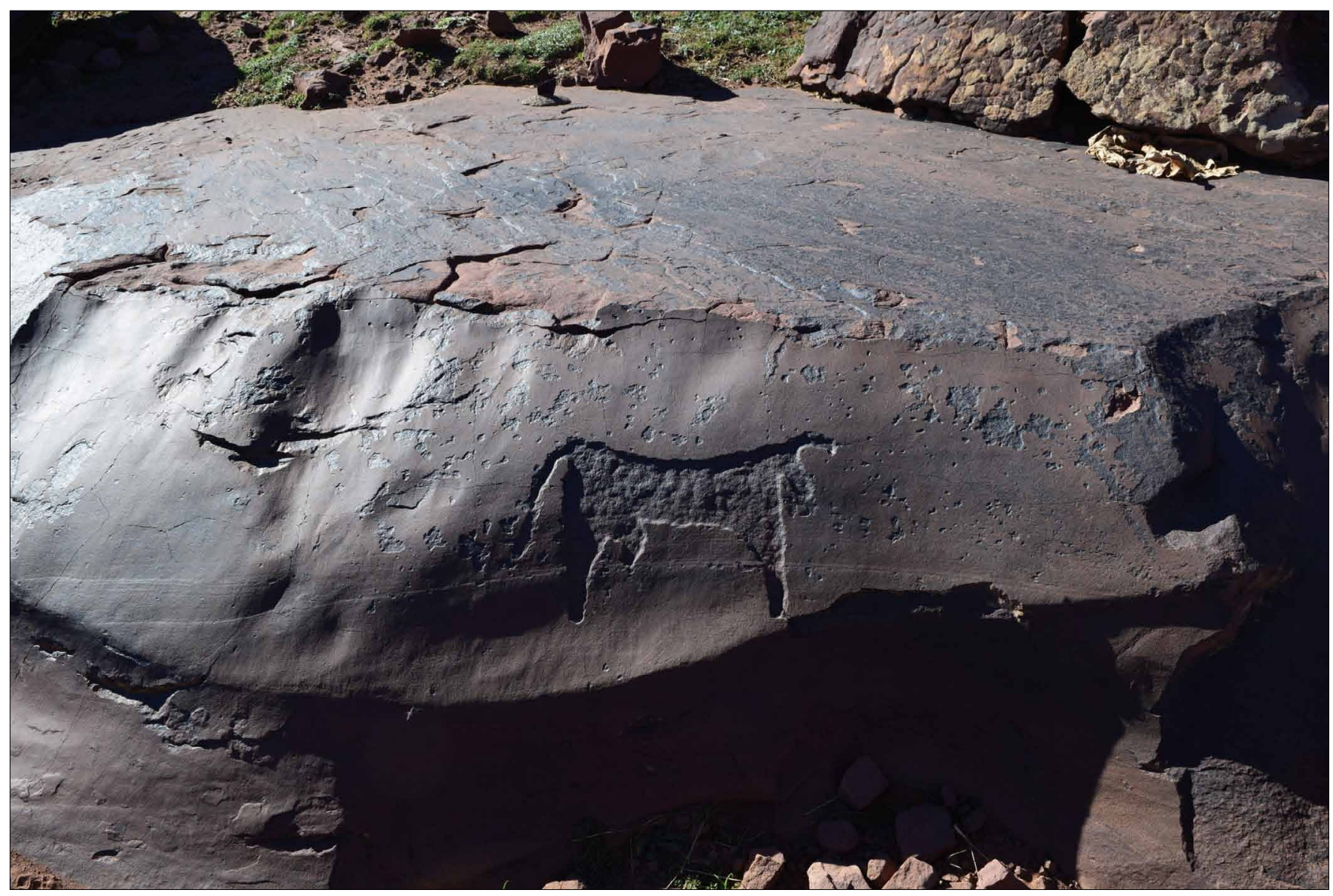

Typology of zoomorphs in the Oukaïmeden Valley - bovine. @ Barbora Půtová.

matic. The latter is based on the morphology of figures and degree of their simplification. A special category is idols, described with morphologic features. Idols are elongated rectangles with round or horizontal ending in the lower part. In a rectangular shape we can identify the body and its partition from the head with narrowing around the neck. Their internal part is empty or divided with transverse lines (Malhomme 1959, 1961; Otto 1994; Rodrigue 1999; Collado Giraldo 2014).

The naturalistic subtype (34 motifs) includes frontally depicted figures complemented with the head, trunk and limbs. These figures are characterized with circular or semi-circular heads. The head area may contain details such as eyes, mouth, nose or ears. The upper and lower limbs of such figures stem from the trunk made by two parallel lines, which results in a trunk with a cylindrical look. Figures have schematized hands and palms. Their upper limbs extended sideways are raised as if praying or adoring, sometimes holding an object. Their lower limbs are directed downwards and are straight, curved or bent at the knees. Figures are usually depicted with clothes or ornaments such as necklaces or bracelets. Later we can see a simplification of features, especially of the lower limbs that are simple lines. Some figures are depicted with weapons, especially daggers (Malhomme 1959, 1961; Rodrigue 1999; Collado Giraldo 2014; Ezziani 2014).
The violin subtype (11 motifs) represents depictions exclusively typical of the Oukaïmeden Valley, unparalleled in the High Atlas. Figures are often linked and compared with Mediterranean Cycladic idols, as this specific method of depicting a female body corresponds with the morphology of the violin (Jodin 1964; Simoneau 1967; Rodrigue 1999). The violinshaped body is hieratical and frontal. The head ends in a long and narrowing neck. Face features are usually schematized; typically only eyes and nose are roughed out. A significant feature of the body is two lateral protrusions that look like voluminous woman's breasts or round-shaped shoulders, extended arms or arms akimbo. However, the figures are not depicted with ornaments or clothes. Sometimes weapons can be seen. Some figures are hit by arrows or spears, whereas some are only surrounded by weapons (Rodrigue 1999; Ezziani 2014). Legs are depicted on both sides, usually curved and rounded at the lower end, which may be a very simplified way of depicting the palms (Le Quellec 2008; Collado Giraldo 2014; Ezziani 2014). “The lower part widens considerably to emphasize what we interpreted as a female sexual organ, which even shows pubic hair depicted as perpendicular lines that fall from the vulvar area." (Collado Giraldo 2014: 149)

The schematic subtype (7 motifs) is characterized with figures in the front perspective whose body is depicted in a simpli- 
fied way with a vertical line forming their head and limbs. The position of the upper and lower limbs changes and varies from their extending to raising as if adoring. Arms usually have fingers, sometimes splayed out like a fan and they may hold various things of disproportionate size such as axes. The lower limbs are often depicted as lines and the body looks like a simple cross. Sometimes the legs are extended horizontally and the body looks like a lizard. Oblique lines may protrude from the trunk of the body and the silhouette thus has the shape of a "tree-like" body. Bodies are complemented with male sexual organs. As the case is with the violin subtype figures, also the schematic subtype figures do not have any ornaments or other accessories. These depictions are usually isolated. If there is any other motif, it is another anthropomorphic figure. The size of the depictions evolved. The initial forms are characterized dynamically with larger figures depicted with undulated limbs. Later, figures became smaller and more hieratic (Collado Giraldo 2014; Ezziani 2014; Torres - Ruiz-Galvéz 2014).

Engravings relating to habits, rites and social structures of inhabitants of the Oukaïmeden Valley testify of the past life in the Oukaïmeden Valley (Nieto 2014). Ethnographic elements include shields, necklaces, topographic maps (or games) and epigraphy. Shields are represented by circular, square and triangular depictions that appear separately, in couples and in groups on the same panel. Shields differ with their size, com position, internal structure or number of geometric elements included. Topographic maps (or games) include depictions made by pecked dots arranged in several lines forming typically a rectangle (Chenorkian 1988; Rodrigue 1999; Collado Giraldo 2014; Ruiz-Galvéz - Torres - Señorán et al. 2015).

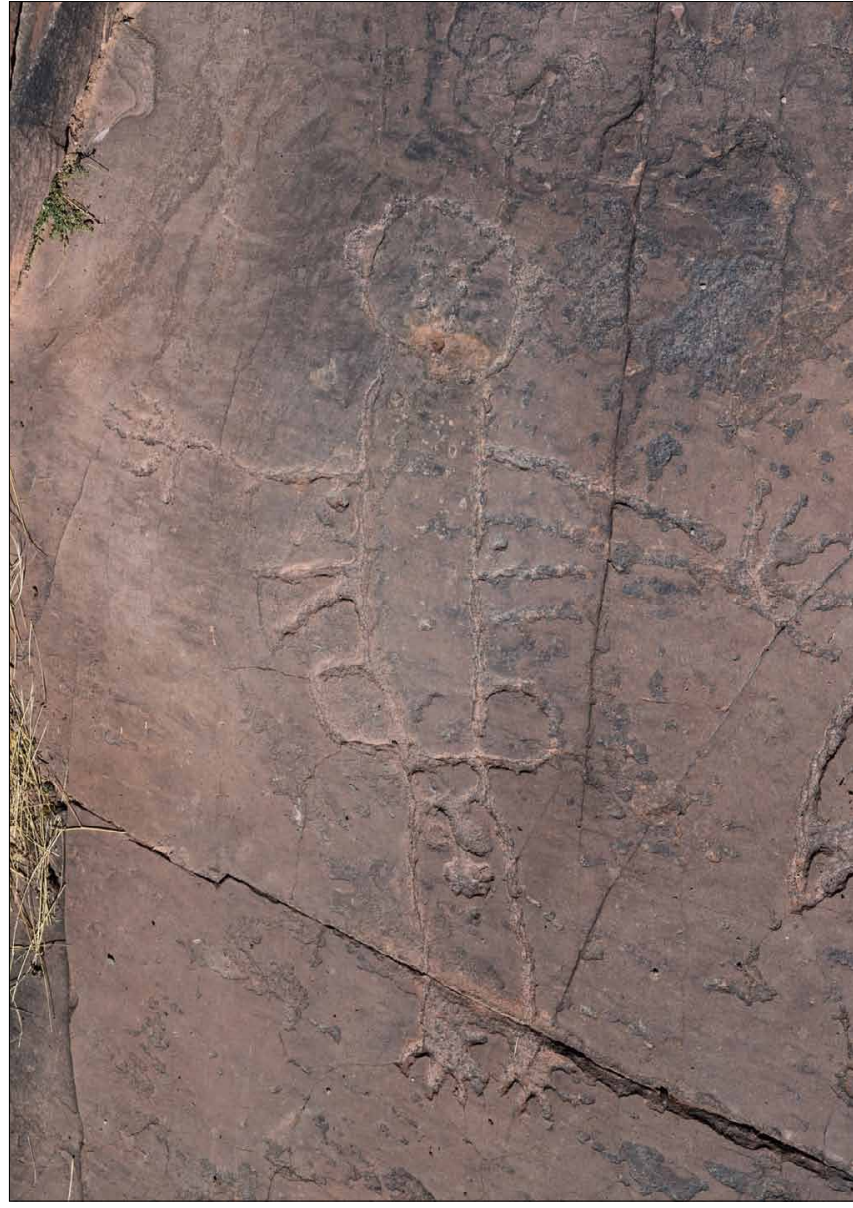

Naturalistic subtype in the Oukaïmeden Valley. @ Barbora Půtová.

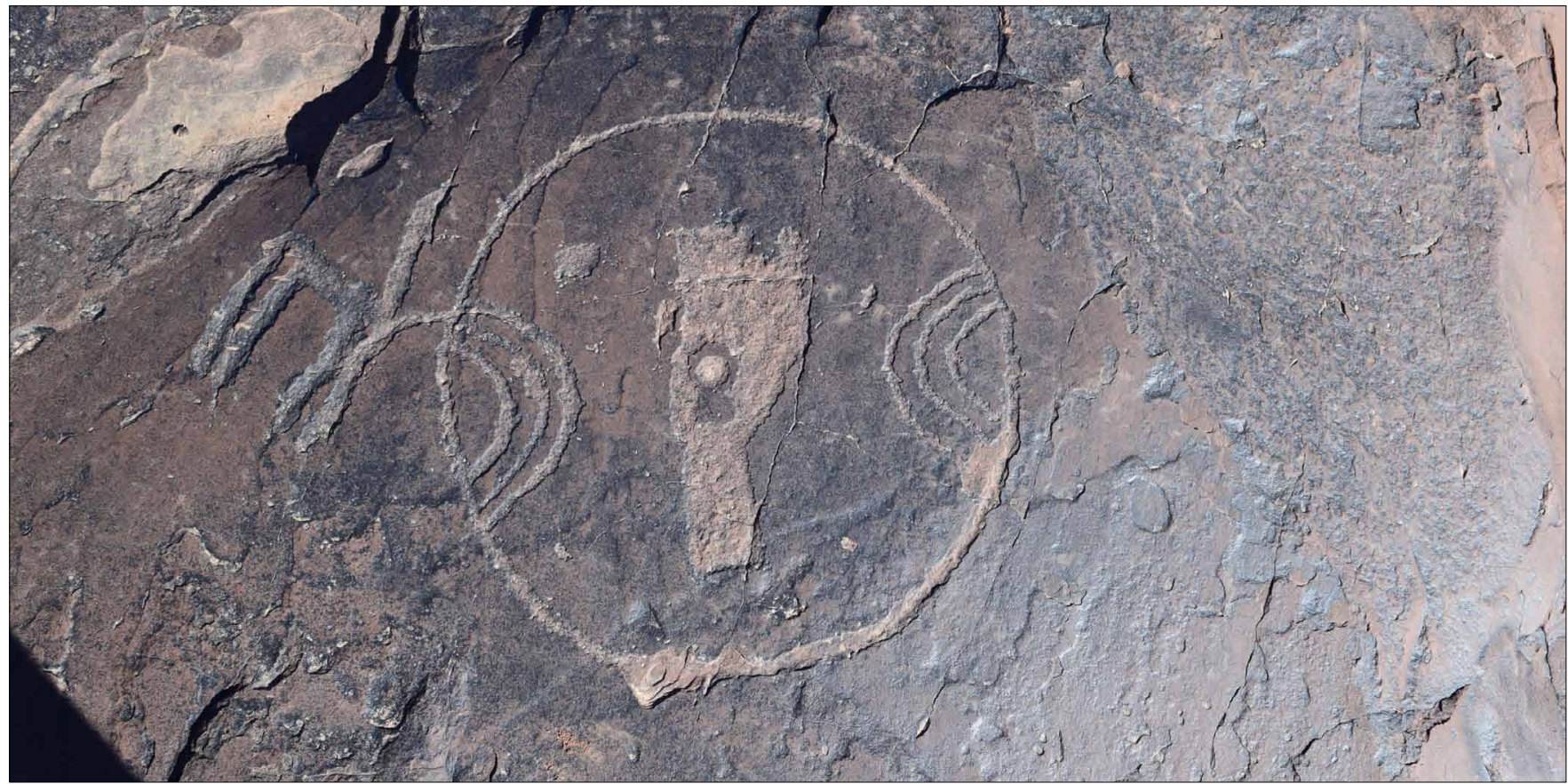

Typology of ethnographical elements in the Oukaïmeden Valley - shield. @ Barbora Půtová. 


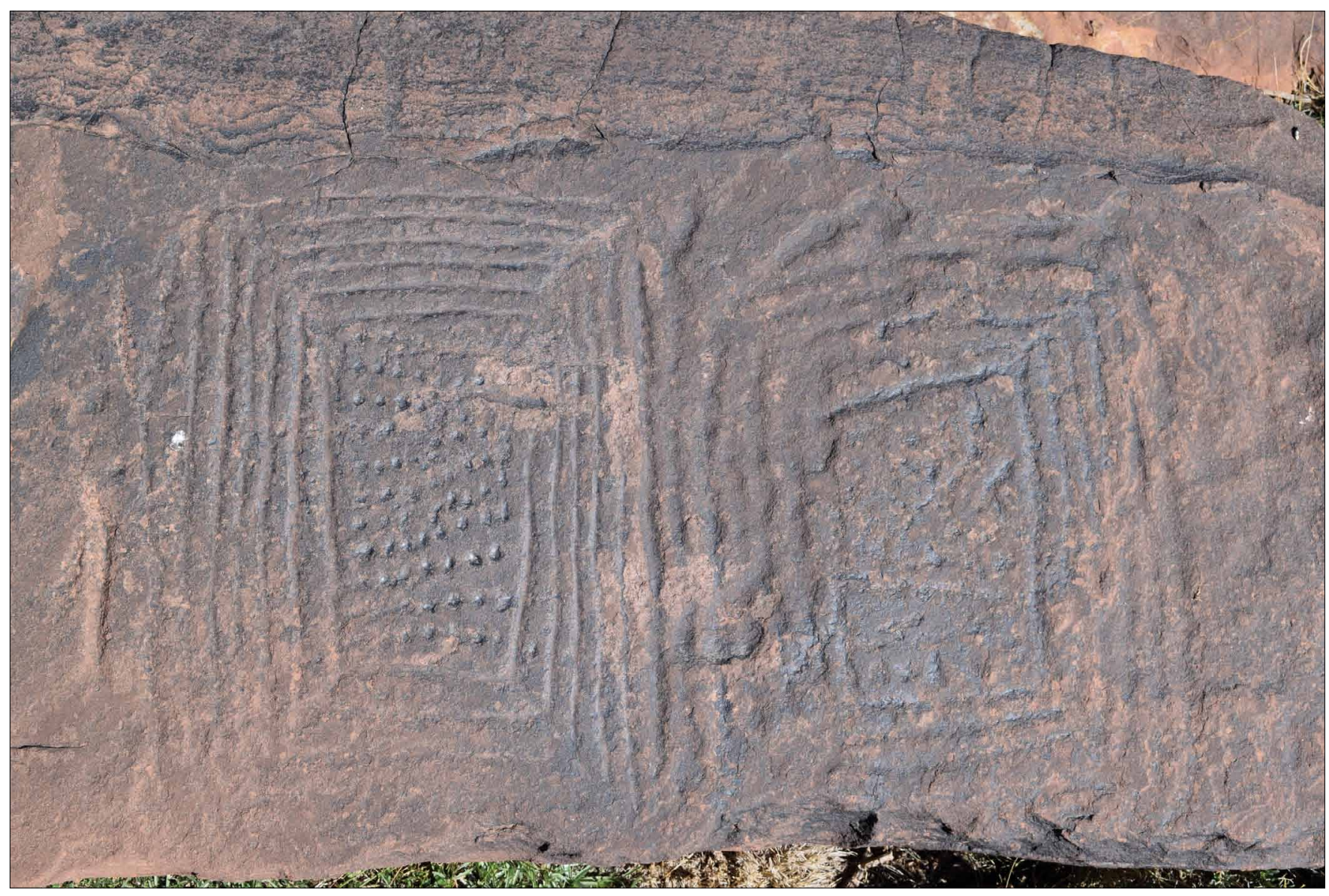

Typology of ethnographical elements in the Oukaïmeden Valley - topographic maps (or games). (c) Barbora Půtová.

These geometrical compositions are considered to represent territorial and landscape features expressing relationships within and between various surrounding rock art panels. Similarly simple depictions are typical for necklaces that are made of curved parallel lines (Arcà 2004; Collado Giraldo 2014).

Symbols represent a wide scale of depictions that are specific to their geometric shapes. In the Oukaïmeden Valley there are linear open structures: straight, simple, double, curved or undulated lines and spirals. Other symbolic forms belong to the category of linear closed structures of forms, squares, rectangles, triangles, tectiforms and also feet. Symbols are usually accompanied by weapons, anthropomorphic and zoomorphic motifs that may overlap or be placed underneath other motifs. Indeterminate motifs do not allow for unambiguous identification: these are fragments of depictions, probably due to schematization or poor state of preservation (Rodrigue 1998; Collado Giraldo 2014).

\section{DATING ROCK ART IN THE OUKAÏMEDEN VALLEY}

Rock art in the High Atlas is the amalgam of artistic trends from the Mediterranean and Sahara. It confirms continuous occupation of the valley since the Middle Holocene period, from the onset of the desiccation process of the Sahara and drier conditions and climate or collapse of the monsoon that resulted in rapid changes in vegetation systems. Plant resources and wild animals became scarce and there was greater cattle mobility in searching for water and pastures (Marshall - Hildebrand 2002; Brooks 2006; Lernia 2006; El Graoui Alifriqui - Jungner et al. 2008; Ruiz-Galvéz - Bokbot - Collado Giraldo et al. 2013). In the Oukaïmeden Valley in the Middle Holocene "the temperature started fluctuating, with short dry periods, due to lower rainfall in winter" (Ruiz Zapata - Gil García - Duque Espino 2014: 136). The oldest evidence of human settlement in the valley and in the High Atlas dates back to the Late Neolithic (Galán - Torres - Señorán 2014; Ruiz-Galvéz - Torres - Señorán 2015). The occurrence of first engravings dates back to this period when zoomorphic motifs appeared. Depictions of animals, one of the main reasons why the valley was exploited, were found at both ends, strategically near pastures (Galán - Torres - Señorán et al. 2014).

In the Early Bronze Age a new depiction occurred - weapons that overlay zoomorphic motifs. "Maces and hammers seem to be the oldest weapon depictions, while swords, daggers and scimitars, some kind of handles, as double appendix ones seem to be more recent." (Torres - Ruiz-Galvéz - Bokbot et al. 




Combination of rock art motifs on a panel in the Oukaïmeden Valley - deer, dagger and idol. () Barbora Půtová.

2012: 171) In the Bronze Age there were changes inside the groups that inhabited the valley. The first evidence of change is the appearance of weapons in the rock art iconography, witnesses of the beginning of social conflicts from competition over access to pasturing resources in mountain areas of a more humid environment and climate. These depictions are systematically distributed throughout the territory, evidence of its higher control (Collado Giraldo 2014). Depictions of weapons in the Oukaïmeden Valley have parallels in the Iberian Peninsula Bronze Age. Some halberds and daggers in the Oukaïmeden Valley correspond with actual weapons from excavations at Early Bronze Age sites such as El Argar and Carapatas in southern Spain (Lull - Mico - Rihuete et al. 2005).

Some of the halberd and dagger types did not have an equivalent in the Iberian Peninsula and are the result of autochthonous development. They correspond with real index fossils and excavated copper or bronze objects in the Oukaïmeden Valley (Chenorkian 1988). These local types of weapons imply that the inhabitants were capable of exploiting the local copper and tin mines. Indigenous people probably first adopted imported models around $1500 \mathrm{BC}$ before producing their own local versions, thereby proving their ability to exploit mineral resources and founding techniques. Morocco and the High Atlas were the borders of the metal area of the West Mediterranean. The High Atlas contains mercury, zinc, copper, manganese, iron ore and barite mines. The discovery of metallurgy entered the High Atlas from the Iberian Peninsula perhaps in the second millennium BC (Malhomme 1950, 1954; Antoine 1954; Laroui 1977; Souville 1986; Searight 2004; Rodrigue 2009).

Weapons complemented anthropomorphic motifs, originally life-sized and carefully executed, which developed into small figures with an increase in schematic shapes and reduction of iconography. The development from naturalism to schematism is apparent in zoomorphic motifs, although most of these engravings did not chronologically go beyond the Bronze Age. Anthropomorphic motifs became central until the Libyan-Berber period (dated from the 1st millennium $\mathrm{BC}$ to the Arabic conquest in the late 7th century AD), when rock art completely disappeared from the Oukaïmeden Valley as well as from the High Atlas as such (Collado Giraldo 2014; Ruiz-Galvéz - Bokbot - Collado Giraldo et al. 2014). "We can only speculate about the reasons for this change, but they could be related to new economic strategies focused in the exploitation of territories and resources located far from the highlands of the Atlas." (Ruiz-Galvéz - Torres - Señorán et al. 2015: 1456). 


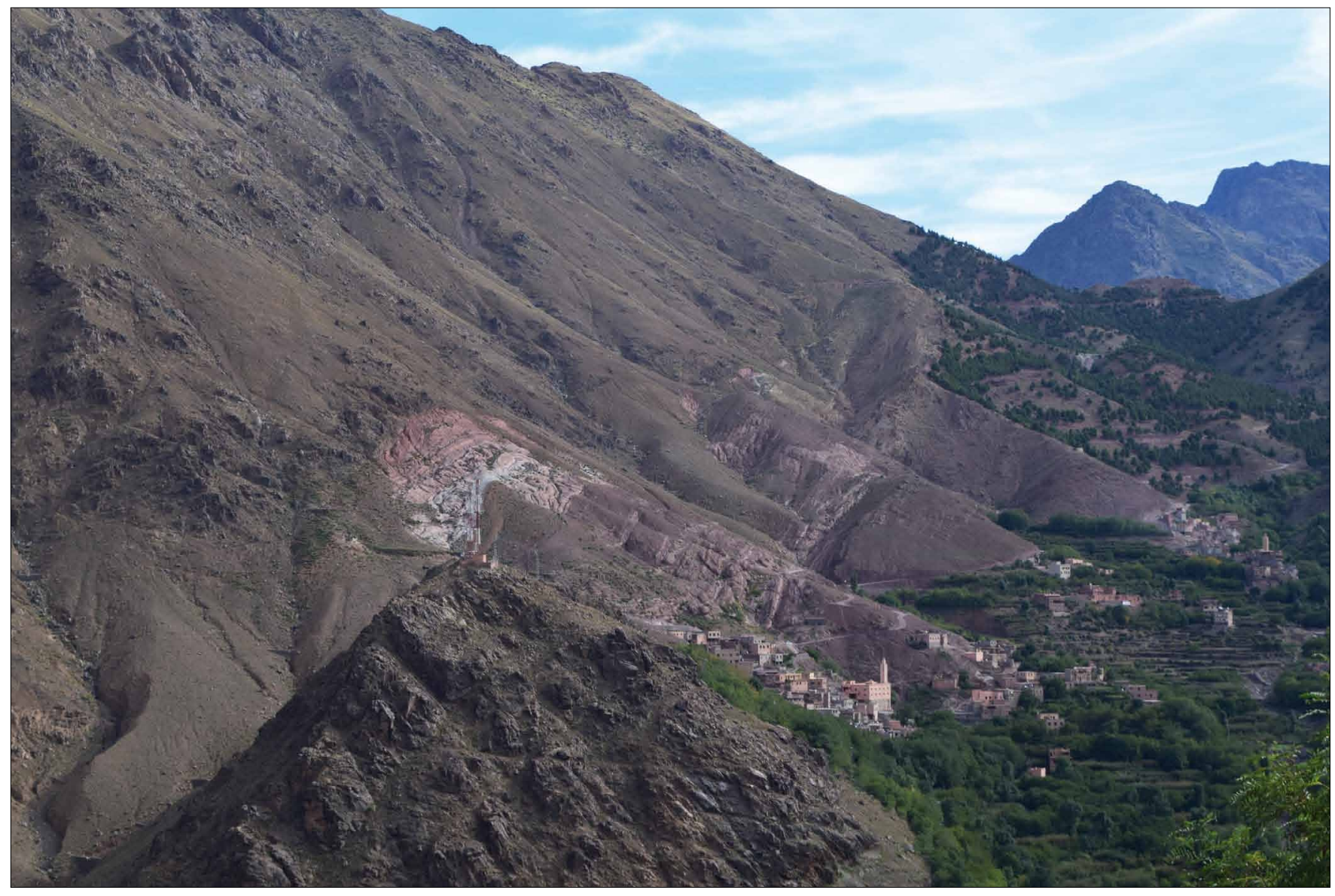

Copper ore deposits on the slopes of the Imlil Valley. @ Barbora Půtová.

\section{INTERPRETATION OF ROCK ART MOTIFS IN THE OUKAÏMEDEN VALLEY}

Seasonal occupation of the valley was an impulse when first engravings of animals were probably the basic form of belief systems. Rock art was situated near resources and routes used by people moving around the valley. Now, shepherds and their herds move in the vicinity of engravings, even walk among them or set up tents. The average distance to them seems to grow through time. While the oldest engravings were placed strategically closer to both sides of the valley and near the centre, the maximum distance substantially increased from the Bronze Age when rock art areas were distributed more systematically farther from the centre of the valley. That is why zoomorphic engravings are frequent near water resources, weapons are concentrated near entrances, while anthropomorphic motifs can be found in marginal areas which may have a connection to rites of passage. This is connected with the visual control over pathways and visibility of rock art from these pathways. In this context, the importance of the place increases as they are not mere geographic coordinates, but symbols that must be interpreted together with other variables such as visibility or navigation. Therefore, it is important to regard engravings as places, representations of the territory and landscape in which they are integrated (Bokbot - Collado Giraldo et al. 2013; Ruiz-Galvéz - Torres - Señorán et al. 2015).

Engravings thus allowed for information exchange within a social organization that could identify the sender, testified of having knowledge of the environment such as presence of water resources, food or predators and marked transhumance routes or territorial rights. A specific message could be intended for group or tribe members, neighbouring groups or enemies. It could have served as a warning or connection with the past of each tribe and transfer of historic experience such as animal catching or hunting. For neighbouring groups or tribes, the engraved shields could have designated the territory of local chiefs, just as anthropomorphic figures "may commemorate a battle hero or a vanquished enemy" (Searight 2013: 41). Some anthropomorphic motifs are hit by arrows and spears or bear traces of deliberate damage and they can be interpreted to be enemies. Rock art served as a communication medium, symbolic meaning of territorial control and a kind of mental map that includes information about entrances, resources, rights of access and prohibitions. From this perspective, rock art in the Oukaïmeden Valley may be linked to oral tradition provided by the shepherds using pastures in the valley. This valley may have been a demonstration of moun- 


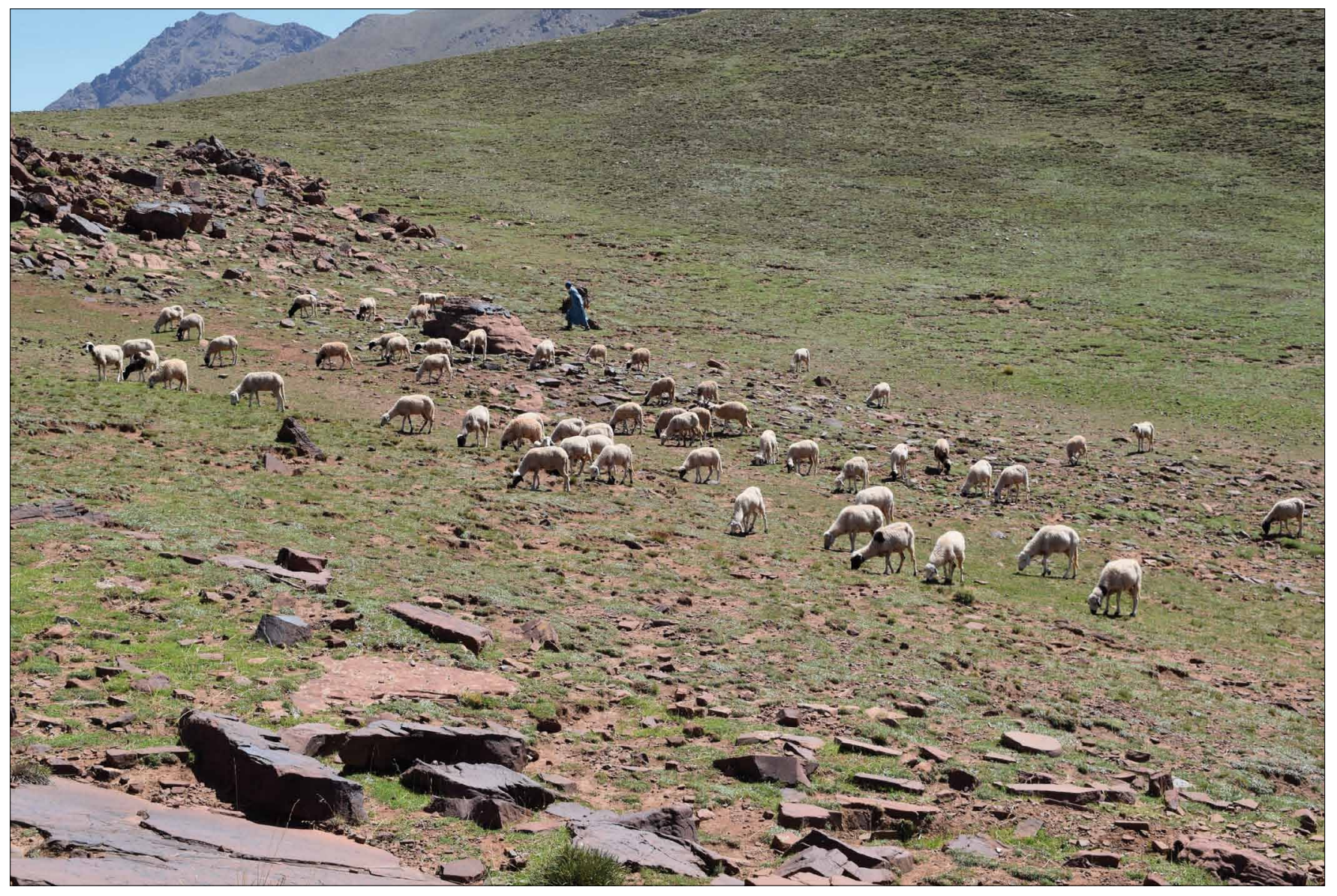

A shepherd and his flock of sheep, grazing and walking amid engravings in the Oukaïmeden Valley. @ Barbora Půtová.

tain cult or the place of worshipping the founding hero and mythical ancestor Sidi Fars, who was the first to enter the valley, demarked pastures and borders of the tribes (Simoneau 1975; Ezziani 2004; Rodrigue 2009; Ruiz-Galvéz - Bokbot Collado Giraldo et al. 2013; Searight 2013; Nieto 2014; RuizGalvéz - Torres - Señorán et al. 2015).

\section{CONNECTION BETWEEN TRANSHUMANCE AND ROCK ART IN THE OUKAÏMEDEN VALLEY}

Rock art in the Oukaïmeden Valley is characterized by a close relation to transhumance, preserved until now. The transhumance in the High Atlas is vertical and includes seasonal mobility of herds of cattle between lowlands and mountain areas (pastures and meadows). The main features of transhumance are adaptability, complexity and use of all natural resources available within a certain territory (between areas) and time (between seasons). Transhumance takes place in valleys where it is the basis of stable settlement of arable pastoral farming with limited areas for farming. Seasonal mobility of cattle thus spares the valley/lowland pastures and resources of hay (Ehlers - Kreutzmann 2000; Akasbi - Oldeland - Dengler et al. 2012). Engravings in the Oukaïmeden Valley are linked to the social and economic role of using mountain pastures with surface area around 800 ha (Malhomme 1950; Jodin 1966; Simoneau 1967; Souville 1991; Salih - Oujaa - Heckendorf et al. 1998; Bourbouze 2000; Searight 2004; Bravin 2014). ${ }^{4}$ Engravings situated near land depressions and water-soaked pastures and springs mark transhumance routes (Ezziani 2004). ${ }^{5}$

4 Since being discovered in 1948, many engravings were destroyed owing to building of the skiing centre. The project resulted in expropriating parts of the pastures. The valley was turned into a tourist centre and old azibs were used for the construction of hotels. Traditional pastoralism was largely replaced with tourism, many shepherds became tourist guides or ski instructors. Space coexistence of Berber shepherds and skiers changed the landscape, perception of the agdal system and weakened bonds to transhumant pastoralism. Nevertheless, still rather a large part of the population is dependent on transhumant pastoral farming, which is either because of their own will or due to the lack of alternatives (Rodrigue 2009; Akasbi Oldeland - Dengler et al. 2012).

5 Wet pastures are sensitive to climatic aspects. Climate changes, anthropic and pastoral pressures and global environmental changes influence the natural environment in the valley. The functioning of the pastures was influenced by hydraulic modifications (construction of the dam in the 1970s) and new adjustments (roads or a drain channel), (Alaoui Haroni - Alifriqui - Simonneaux 2009). 


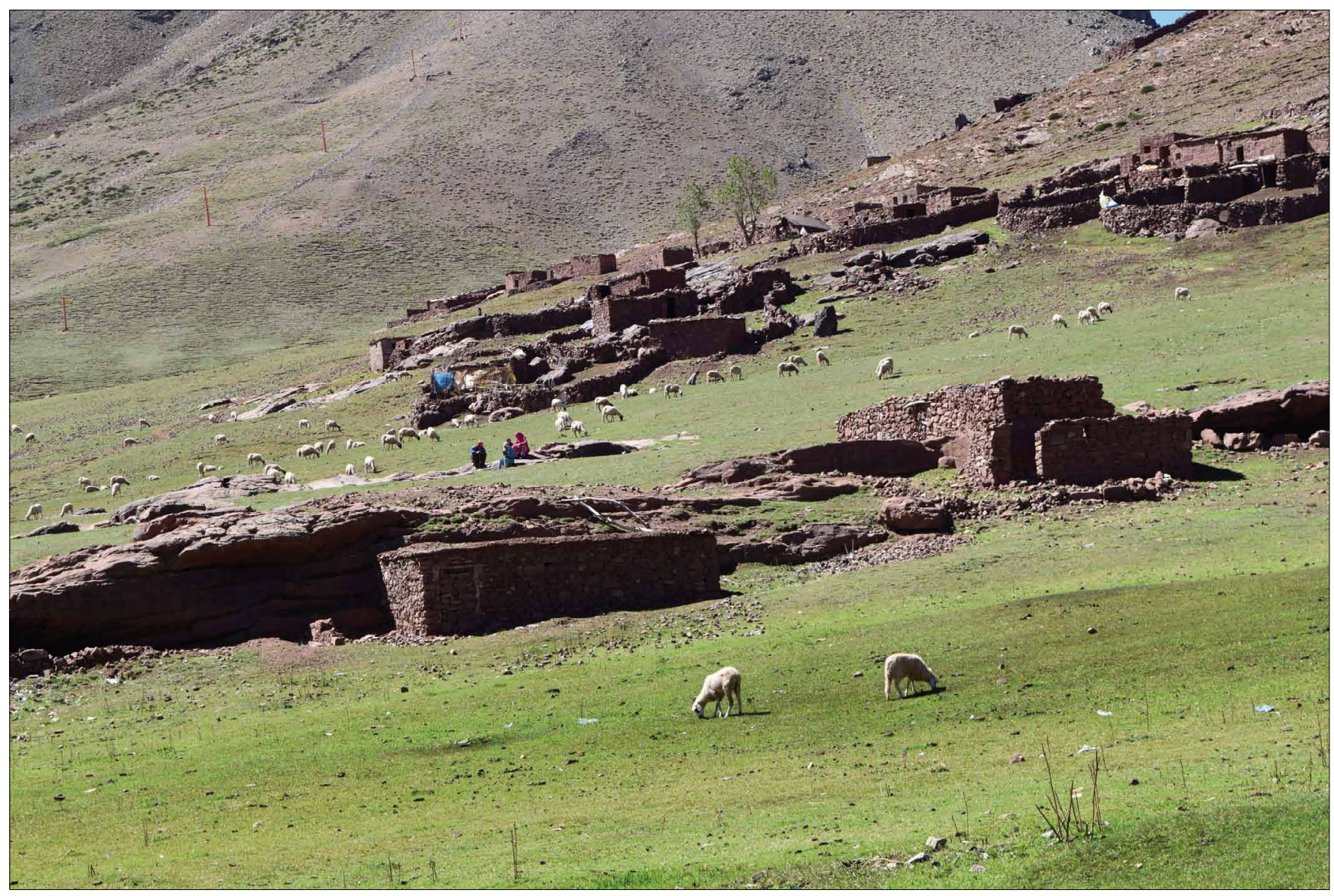

Women remain close to the houses (azibs) in the Oukaïmeden Valley. (C) Barbora Půtová.

Pastures in the Oukaïmeden Valley are used by two groups of Berber shepherds enter the valley: the Rheraya tribe from the West and the Ourika tribe from the East (Ruiz-Galvéz - Bokbot - Collado Giraldo et al. 2013). Using collective pastures in the Oukaïmeden is subject to the agdal system (evergreen meadow) which "traditionally refers to collective pasture governed and managed by a local assembly of elderly men representing the tribes of the confederation who fix the opening and closing of pasture" (Ilahiane 2006: 10). It is a set of rights, rites and rules that regulate collective use of the pastures in the valley. The regulation determines the period when access to the valley is allowed and designates the territory used by each group of shepherds. Access to the pastures is prohibited every year from 15 March to 10 August. The ban on access ends with an opening rite and cattle entering the valley from mountain passes. The duration of the journey shepherds have to take depends on the kind of animals, but it usually doesn't last more than a day. The date of return around 28 September can be explained by first snow and exhausting the pastures after they have been exploited for two months (Ilahiane 1999; Mahdi 1999, 2010; Nieto 2014).

Shepherds settle in the valley in mountain villages (azibs), summer grazing settlements that have a similar structure, simplicity and concentration in the landscape. These settle- ments are usually small groups of stone houses: their type, size and solidness of construction depend on how long groups remain on the pastures. Settlements facilitate shepherds' mobility and fencing of the livestock. Shepherds' activities are divided by sex. Men herd the goats and sheep, women take care of cows, cattle foraging and housework, cooking and childcare. Women also pick medicinal herbs or weave rugs (Ezziani 2004; Alaoui Haroni - Alifriqui - Simonneaux 2009; Mahdi 2010; Nieto 2014).

Restrictions and access are based on the customary law aimed at restoration of pastures for protecting and preserving the local biodiversity. Regulated use of resources allows for their annual use and spring protection of plants, inflorescence and ripening of young plants. Pastures are the place of social and ecologic balance production and reproduction that is necessary for sustainability of pastoral life and pasture management. Harsh climate in the mountains restricts access to pastures in autumn and winter months, whereas in summer the parched lowlands are too hot for shepherds and their animals. The duration of the agreement to use the pastures depends on the consent of pastoral groups and their awareness of it. Knowledge of the tradition was passed on orally until the late twentieth century. Although no borderlines between the pasture of the Rheraya and Ourika tribes are marked, the shep- 
herds know them very well and respect them (Gellner 1969; Auclair 1998; Finckh - Goldbach 2010; Alaoui Haroni - Alifriqui 2012; Nieto 2014). ${ }^{6}$

Vertical transhumance still has strategic importance for agropastoral communities of the High Atlas. The tribes using seasonally the Oukaïmeden Valley follow traditional behaviour patterns that are common for the Mediterranean transhumance model. From this perspective, the production of rock engravings documents relations between three principles that are still integrated in the agdal system: resources of grazing, their use and ownership (power and territory) and ritual and symbolic system. Therefore, the position of engravings in the Oukaïmeden Valley was deliberate. "The integration of the carvings in this human landscape - 'human' because it is interpreted and modified by man - changes our perspective about the places where they were made." (Nieto 2014: 193) Selecting the place for applying a motif was made in accordance with several parameters, such as cardinal orientation, inclination, type of surface or iconography that were part of the limited territory source control programme (Alaoui Haroni - Alifriqui 2012; Nieto 2014).

6 The same applies to access to resources that is collectively known. In case of breaching the ban, a financial fine may be imposed (at present for instance 1,000 Moroccan dirhams) or the fine may be in a different form (goat or cow), (Nieto 2014).

\section{REFERENCES}

Akasbi, Z. - Oldeland, J. - Dengler, J. et al. (2012): Social and Ecological Constraints for Decision Making by Transhumant Pastoralists: A Case Study from the Moroccan Atlas Mountains. Journal of Mountain Science, $9,307-321$.

Alaoui Haroni, S. - Alifriqui, M. (2012): Approche écologique des pâturages humides d'altitude et pratiques de gestion. Le plateau d'Oukaïmeden dans le Haut Atlas de Marrakech. In: Auclair, L. - Alifriqui, M., Eds., Agdal: Patrimoine socioécologique de l'Atlas marocain. Rabat: IRD - IRCAM, 75-92.

Alaoui Haroni, S. - Alifriqui, M. - Simonneaux, V. (2009): Recent Dynamics of the Wet Pastures at Oukaïmeden Plateau (High Atlas Mountains, Morroco). Biodiversity and Conservation, 18(1), 167-189.

Antoine, M. (1954): L'industrie accompagnant les gravures rupestres de l'Oukaïmeden. Publications du Service des Antiquités du Maroc, 10, 11-24.

Arcà, A. (2004): The Topographic Engravings of Alpine Rock-Art: Fields, Settlements and Agricultural Landscapes. In: Chippindale, C. - Nash, G., Eds., The Figured Landscapes of Rock-Art. Cambridge: Cambridge University, 318-349.

Auclair, L. (1998): Les ressources sylvopastorales au Maghreb. Structure segmentaire et appropriation communautaire. In: Rossi, G. - Delville, P.L. - Narbeburn, P., Eds., Sociétés rurales et environnement: gestion des ressources et dynamiques locales au Sud. Paris: Karthala, 123-140.

Bourbouze, A. (2000): Pastoralisme au Maghreb: la révolution silencieuse. Fourrages, 161, 3-21.

Bravin, A. (2009): Les gravures rupestres libyco-berbères de la région de Tiznit (Maroc). Paris: L'Harmattan.

Bravin, A. (2014): History of Research in the High Atlas. Past and Present of Research in the Oukaïmeden Valley. Complutum, 25(2), 25-31.

Brooks, N. (2006): Cultural Responses to Aridity in the Middle Holocene and Increased Social Complexity. Quaternary International, 151, 29-49.
Ehlers, E. - Kreutzmann, H. (2000): High Mountain Ecology and Economy: Potential and Constrains. In: Ehlers, E. - Kreutzmann, H., Eds., High Mountain Pastoralism in Northern Pakistan. Stuttgart: Franz Steiner Verlag, 9-36.

El Graoui, M. - Alifriqui, M. - Jungner, H. et al. (2008): Recherches d'indices chronologiques sur le paysage des graveurs de rochers de l'Oukaïmeden (Haut-Atlas, Maroc). Sahara, 19, 105-108.

Ezziani, El H. (2004): Une classification morphologique des figures anthropomorphes. (Gravures rupestres du Haut Atlas). La vallée de l'Ourika (Maroc). L'Anthropologie, 108(3), 495-534.

Collado Giraldo, H. (2014): Main Characteristics of Oukaïmeden Rock Art (Morocco). Complutum, 25(2), 141-166.

Finckh, M. - Goldbach, H. (2010): Vegetation Dynamics Under Climate Stress and Land Use Pressure in the Drâa Catchment. In: Speth, P. - Christoph, M. - Doekkrüger, B., Eds., Impacts of Global Change on the Hydrological Cycle in West and Northwest Africa. Heidelberg: Springer, 274-281.

Galán, E. - Torres, J. de - Señorán, J. M. (2014): Archaeological Interventions. In Search of Traces of the Human Presence in the Valley. Complutum, 25(2), 45-76.

Gellner, E. (1969): Saints of the Atlas. London: Weidenfield and Nicholson.

Glory, A. (1953): Gravures rupestres du Haut Atlas. Un épisode guerrier de l'histoire berbère. La Nature, 3218, 174-180.

Chenorkian, R. (1988): Les armes metalliques dans I'art protohistorique de I'Occident mediterraneen. Paris: CNRS.

Ilahiane, H. (1999): The Berber Agdal Institution: Indigenous Range Management in the Atlas Mountains. Ethnology, 38, 21-45.

Ilahiane, H. (2006): Historical Dictionary of the Berbers (Imazighen). Lanham: Scarecrow Press.

Jodin, A. (1964): Les gravures rupestres du Yagour (Haut-Atlas): Analyse stylistique et thématique. Bulletin d'Archéologie Marocaine, 5, 47-116.

Jodin, A. (1966): Les gravures rupestres de l'Oukaïmeden (Haut-Atlas): Documents inedits. Bulletin d'Archéologie Marocaine, 6, 29-54.

Kaache, B. (2001): Archéologie de l'art rupestre: analyse du bestiaire gravé du Présahara marocain. Oxford: Archaeopress.

Laroui, A. (1977): The History of the Maghrib: An Interpretive Essay. Princeton: Princeton University Press.

Lernia, S. di (2006): Building Monuments, Creating Identity: Cattle Cult as a Social Response to Rapid Environmental Changes in the Holocene Sahara. Quaternary International, 151, 50-62.

Lull, V. - Mico, R. - Rihuete, C. et al. (2005): Property Relations in the Bronze Age of South-Western Europe: An Archaeological Analysis of Infant Burials from El Argar (Almeria, Spain). Proceedings of the Prehistoric Society, 71, 247-268.

Mahdi, M. (1999): Pasteur de l'Atlas, production pastorale, droit et rituel. Casablanca: Imprimerie Najah.

Mahdi, M. (2010): Patrimonialisation de la transhumance à l'Oukaïmeden. In: Lerin F., Ed., Pastoralisme méditerranéen: patrimoine culturel et paysager et développement durable. Montpellier: CIHEAM / AVECC / UNESCO, 73-83.

Malhomme J. (1950): Les pierres excavées et les gravures rupestres du Grand Atlas de Marrakech. Bulletin de la Société de Préhistoire du Maroc, 2, 7-21.

Malhomme J. (1954): Representations des haches du Bronze (Grand Atlas). Bulletin de la Société de Préhistoire du Maroc, 7-8, 3-7.

Malhomme, J. (1959): Corpus des gravures rupestres du Grand Atlas (lère partie). Rabat: Service des antiquités du Maroc.

Malhomme, J. (1961): Corpus des gravures rupestres du Grand Atlas (2ère partie). Rabat: Service des antiquités du Maroc.

Marshall, F. - Hildebrand, E. (2002): Cattle Before Crops: The Beginnings of Food Production in Africa. Journal of World Prehistory, 16, 99-143.

Nieto, C. (2014): Tradition and Modernity in the Oukaïmeden Valley: Changes in the Rites and Practices of Seasonal Transterminance. Complutum 25(2), 191-207.

Otto, J. (1994): Spuren der Vergangenheit: Prähistorische Felsgravuren im Hohen Atlas I. Marokko. Lollschied: Kult-Ur-Institut für Interdisziplinäre Kulturforschung.

Půtová, B. (2015): Skalní umění: portugalská naleziště Foz Côa a Mazouco. Praha: Univerzita Karlova v Praze, nakladatelství Karolinum.

Le Quellec, J.-L. (2008): What's New in the Sahara, 2000-2004? In: Bahn, P. Franklin, N. - Strecker, M., Eds., Rock Art Studies: News of the World III. Oxford: Oxbow Books, 52-88. 
Rodrigue, A. (1998): Nouvelles gravures inédites à l’Oukaïmeden (Atlas marocain). Sahara, 10, 117-118

Rodrigue, A. (1999): L’art rupestre du Haut Atlas marocain. Paris: L’Harmattan.

Rodrigue, A. (2009): L'art rupestre au Maroc: les sites principaux. Des pasteurs du Dra aux métallurgistes de l'Atlas. Paris: Harmattan.

Ruiz-Galvéz, M. - Bokbot, Y. - Collado Giraldo et al. (2013): Rock Art, Landscape and Prehistoric Settlement at the High Atlas (Morocco). In: Contreras, F. - Farjas, M. - Melero, F. J., Eds., Proceedings of the 38th Annual Conference on Computer Applications and Quantitative Methods in Archaeology. Oxford: Archaeopress, 287-290.

Ruiz-Galvéz, M. - Presa, P. de la (2014): A Proposal for Integration of Heritage and Tourism. Complutum, 25(2), 229-234.

Ruiz-Galvéz, M. - Bokbot, Y. - Collado Giraldo et al. (2014): Conclusions and New Avenues for Analysis. Complutum, 25(2), 237-240

Ruiz Zapata, M. B. - Gil García, M.-J. - Duque Espino, D. (2014): Vegetation History in the Oukaïmeden Valley. Human Action and the Evolution of the Landscape. Complutum, 25(2), 123-137.

Ruiz-Galvéz, M. - Torres, J. de - Señorán, J. M. et al. (2015): Rock Art and Mountain Landscape (Oukaïmeden Valley, High Atlas, Morocco). In: Collado Giraldo, H. - García Arranz, J. J., Eds., XIX International Rock Art Conference IFRAO 2015. Symbols in the Landscape: Rock Art and Its Context. Tomar: Instituto Terra e Memória, 1437-1457.

Salih, A. - Oujaa, A. - Heckendorf, R. et al. (1998): L'aire rupestre de l'Oukaïmeden, Haut Atlas, Maroc: Occupation humaine et économie. Beiträge zur Allgemeinen und Vergleichenden Archäologie, 18, 253-295.

Searight S. (2004): The Prehistoric Rock Art of Morocco: A Study of Its Extension, Environment and Meaning. Oxford: Archaeopress.

Searight S. (2013): Morocco's Rock Art: Age and Meaning. Arts, 2, 35-43.

Simoneau, A. (1967): Les gravures du Haut Atlas de Marrakech. Revue Géographie Maroc, 11, 67-76.

Simoneau, A. (1975): Protohistoire religieuse du Jebel Rhat (Haut Atlas). In: Valcamonica Symposium 72. Actes du Symposium International sur les Religions de la Prehistoire. Capo di Ponte: Centro Camuno di Studi Preistorici, 335-342.

Simoneau, A. (1977): Catalogue des sites rupestres du sud marocain. Rabat: Ministère d'État chargé des Affaires Culturelles.

Souville, G. (1986): Témoignages sur lâge du bronze au Maghreb occidental. Comptes Rendus des Séances de l'Académie des Inscriptions et Belles-Lettres, 130, 97-114.

Souville, G. (1991): Essai d'interprétation des gravures rupestres du Haut Atlas marocain. Comptes rendus des séances de l'Académie des Inscriptions et Belles-Lettres, 135(4), 767-782.

Torres, J. de - Ruiz-Galvéz, M. (2014): Unravelling Patterns in Oukaïmeden Rock Art. Complutum, 25(2), 167-187.
Torres, J. de - Ruiz-Galvéz, M. - Bokbot, Y. et al. (2012): Traditional Wisdom and Landscape Management. A Longue durée History of Human Exploitation of a Critical Resource. The Case of the Oukaïmeden Valley (High Atlas, Morocco). In: García, A., Ed., Debating Spatial Archaeology. Proceedings of the International Workshop on Landscape and Spatial Analysis in Archaeology. Santander: Instituto Internacional de Investigaciones Prehistoricas de Cantabria, 167-178.

\section{AUTHOR}

Barbora Půtová is a Czech anthropologist and art historian lecturing at the Faculty of Arts, Charles University in Prague. She deals with history of culture, artwork and cultural heritage. Other fields of her expert interest include historical anthropology, visual anthropology and anthropology of art. She has published dozens of articles and experts studies as well as several expert monographs such as Pravěké uměni (Prehistoric Art, co-authors Jean Clottes and Václav Soukup, 2011), Félicien Rops: enfant terrible dekadence (Félicien Rops: Enfant Terrible of Decadence, 2013), Kristkova podyjská glyptotéka (Kristek's Dyje Valley Glyptotheca, co-author Iveta K. Pavlovičová, 2013), The Genesis of Creativity and the Origin of the Human Mind (co-edited by Václav Soukup, 2015) or Královská cesta: všední i sváteční život v proměnách času (The Royal Route: Ordinary and Festive Life Over the Course of Time, 2016). In her monograph Félicien Rops she offers the first comprehensive view of the life and work of one of the most prominent representatives of decadence and symbolism; in her last book Královská cesta (The Royal Route) she writes about the creation, development, meaning and historical changes of the Royal Route in Prague. In her book Skalní uméní (Rock Art, 2015), she published the results of her field research of Palaeolithic art that she carried out at archaeological sites in France and Portugal. At presents she is carrying out research of African rock art in the High Atlas Mountains of Morocco.

Contact: PhDr. Mgr. Barbora Půtová, Ph.D. et Ph.D., Ústav etnologie Filozofické fakulty Univerzity Karlovy, Celetná 20, 110 00, Praha 1, e-mail: barbora.putova@ff.cuni.cz

\section{ACKNOWLEDGEMENT}

Special thanks go to CK Blue Style k.s. for their support during my stay and research in the Oukaïmeden Valley.
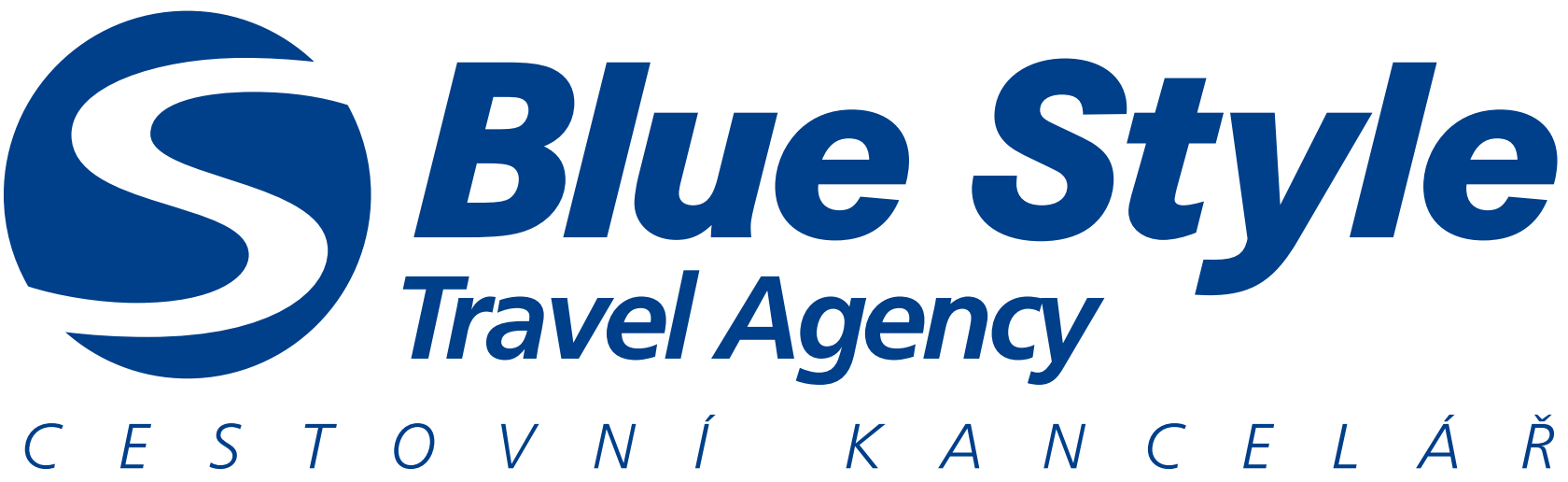